\title{
Effect of lithium fluoride on thermal stability of proton-conducting $\mathrm{Ba}(\mathrm{ZrO} .8-$ xCexY0.2)O2.9 ceramics
}

\author{
Authors: C.-S. Tu, C.-C. Huang, S.C. Lee, R.R. \\ Chien, V.H. Schmidt, and C.-L. Tsai
}

NOTICE: this is the author's version of a work that was accepted for publication in Solid State lonics. Changes resulting from the publishing process, such as peer review, editing, corrections, structural formatting, and other quality control mechanisms may not be reflected in this document. Changes may have been made to this work since it was submitted for publication. A definitive version was subsequently published in Solid State Ionics, VOL\# 181, ISSUE\# 37/38, (2010), DOI\# 10.1016/j.ssi.2010.09.052.

C.-S. Tu, C.-C. Huang, S.C. Lee, R.R. Chien, V.H. Schmidt, and C.-L. Tsai, "Effect of lithium fluoride on thermal stability of proton-conducting $\mathrm{Ba}(\mathrm{Zr0}$.8-xCexY0.2)O2.9 ceramics," Solid State lonics 181, 1654-1658 (2010). doi: 10.1016/j.ssi.2010.09.052.

Made available through Montana State University's ScholarWorks

scholarworks.montana.edu 


\title{
Effect of lithium fluoride on thermal stability of proton-conducting $\mathrm{Ba}\left(\mathrm{Zr}_{0.8-x} \mathrm{Ce}_{x} \mathrm{Y}_{0.2}\right)$ $\mathrm{O}_{2.9}$ ceramics
}

\author{
C.-S. Tu ${ }^{\text {a, } * \text {, C.-C. Huang }}{ }^{\text {a }}$, S.C. Lee ${ }^{\text {a }}$, R.R. Chien ${ }^{\text {b }}$, V.H. Schmid ${ }^{\text {b }}$, C.-L. Tsai ${ }^{\text {b }}$ \\ a Department of Physics, Fu Jen Catholic University, Taipei 242, Taiwan, Republic of China \\ ${ }^{\mathrm{b}}$ Department of Physics, Montana State University, Bozeman, MT 59717, USA
}

\begin{abstract}
A B S T R A C T
In-situ X-ray diffraction (XRD) and micro-Raman scattering have been used to study the thermal stability of lithium fluoride (LiF)-added (7\% weight ratio) $\mathrm{Ba}\left(\mathrm{Zr}_{0.8-x} \mathrm{Ce}_{x} \mathrm{Y}_{0.2}\right) \mathrm{O}_{2.9}$ (BZCY: $x=0.1$ and 0.2 ) protonconducting ceramic powders as a function of temperature in $1 \mathrm{~atm}$ of flowing $\mathrm{CO}_{2}$. This work reveals that LiFaddition can reduce the thermal stability of $\mathrm{Ba}\left(\mathrm{Zr}_{0.8-x} \mathrm{Ce}_{x} \mathrm{Y}_{0.2}\right) \mathrm{O}_{2.9}$ in $\mathrm{CO}_{2}$ and cause decomposition to $\mathrm{BaCO}_{3}$, and possibly $\mathrm{Ba}_{3} \mathrm{Ce}_{2}\left(\mathrm{CO}_{3}\right)_{5} \mathrm{~F}_{2}$ (or $\mathrm{CeCO}_{3} \mathrm{~F}$ ), and $\mathrm{Y}_{2} \mathrm{O}_{3}$-like compound after exposure to $\mathrm{CO}_{2}$ from high temperatures. LiF-related compounds can be removed after calcining (or sintering) in air above $1200{ }^{\circ} \mathrm{C}$, but a minor amount of a $\mathrm{Y}_{2} \mathrm{O}_{3}$-like compound could remain after calcining at $1400{ }^{\circ} \mathrm{C}$ in air.
\end{abstract}

\section{Introduction}

One important issue facing proton-conducting ceramics for applications of hydrogen purification and solid oxide fuel cells (SOFCs) is the thermal instability to the environment, especially reaction with coal syngas components such as $\mathrm{CO}_{2}$ and $\mathrm{H}_{2} \mathrm{~S}[1,2]$. However, the effects of coal syngas species on SOFC related materials are not presently well known. Though proton conductors are promising candidates for SOFCs because of their low ionic activation energy [3-6], the major challenge for these materials is to find a proper compromise between ionic conductivity and thermal (or chemical) stability in various environments and operation temperatures (typically $700-850{ }^{\circ} \mathrm{C}$ ).

$\mathrm{BaCeO}_{3}$ has been known to exhibit high ionic conductivity at high temperatures $\left(\geq 500{ }^{\circ} \mathrm{C}\right)$ but a poor thermal stability was observed in $\mathrm{CO}_{2}$ and $\mathrm{H}_{2} \mathrm{O}$ atmospheres [3-7]. On the other hand, yttrium-doped $\mathrm{BaZrO}_{3}$ shows a sufficient thermal stability $[8,9]$. $\mathrm{Zr}$ substitution for Ce can improve the thermal stability but decreases the ionic conductivity. Partially substituting $\mathrm{Zr}$ for Ce reduces its tendency to decompose into $\mathrm{BaCO}_{3}$ and other oxides in a $\mathrm{CO}_{2}$-containing environment at intermediate temperatures $\left(700-850^{\circ} \mathrm{C}\right)$. Thus, it has been a goal to find doped $\mathrm{Ba}(\mathrm{Zr}, \mathrm{Ce}) \mathrm{O}_{3}$ ceramics with sufficient ionic conductivity and thermal stability by replacing a fraction of cerium with $\mathrm{Zr}$ or other stable dopants.
By thermal gravimetric analysis (TGA) and XRD, $\mathrm{Ba}\left(\mathrm{Ce}_{0.9} \mathrm{Y}_{0.1}\right) \mathrm{O}_{3-\delta}$ (BCY10) powder was confirmed to be kinetically stable below $500{ }^{\circ} \mathrm{C}$ and then decomposes completely to $\mathrm{BaCO}_{3}, \mathrm{CeO}_{2}$, and $\mathrm{Y}_{2} \mathrm{O}_{3}$ after exposure to pure $\mathrm{CO}_{2}$ at $860^{\circ} \mathrm{C}$ [10]. Similarly, XRD results of $\mathrm{BCY} 10$ heated in the region of $700-1000{ }^{\circ} \mathrm{C}$ in pure $\mathrm{CO}_{2}$ revealed $\mathrm{BaCO}_{3}$ and fluorite-like $\mathrm{CeO}_{2}$ structures [11]. It was found that BCY10 can absorb $0.13 \mathrm{~g}$ of $\mathrm{CO}_{2}$ per ceramic gram [11]. $\mathrm{Ba}\left(\mathrm{Ce}_{0.9} \mathrm{Nd}_{0.1}\right) \mathrm{O}_{3-\delta}(\mathrm{BCN})$ ceramic showed decomposition to $\mathrm{BaCO}_{3}$ and $\mathrm{CeO}_{2}$ in $1 \mathrm{~atm} \mathrm{CO}_{2}$ before reaching $1200^{\circ} \mathrm{C}$, above which the $\mathrm{BCN}$ ceramics reacted with alumina or zirconia in the crucible, leading to the loss of barium and an excess of cerium [12]. Differential thermal analysis (DTA) and TGA of $\mathrm{Gd}$ - and $\mathrm{Nd}$-doped $\mathrm{Ba}(\mathrm{Ce}, \mathrm{Zr}) \mathrm{O}_{3}$ solid solutions showed a reaction with $\mathrm{CO}_{2}$ above $600{ }^{\circ} \mathrm{C}$ and a reverse reaction near $1150{ }^{\circ} \mathrm{C}$ for low $\mathrm{Zr}$ content [13].

$\mathrm{Ba}\left(\mathrm{Zr}_{0.4} \mathrm{Ce}_{0.5}\right) \mathrm{Y}_{0.1} \mathrm{O}_{3-\delta}$ showed a good thermal stability after exposure to $\mathrm{CO}_{2}$ at $900{ }^{\circ} \mathrm{C}$ [13]. The total ionic conductivity of $\mathrm{Ba}$ $\left(\mathrm{Zr}_{x} \mathrm{Ce}_{0.9-x} \mathrm{Y}_{0.1}\right) \mathrm{O}_{3-\delta}(x=0.0-0.9)$ in wet $\mathrm{H}_{2}\left(p \mathrm{H}_{2} \mathrm{O}=1.7 \times 10^{3} \mathrm{~Pa}\right)$ varies from $3.5 \times 10^{-2}$ to $3.0 \times 10^{-3} \mathrm{~S} / \mathrm{cm}$ at $800{ }^{\circ} \mathrm{C}$ [14]. The XRD spectra of $\mathrm{Ba}\left(\mathrm{Zr}_{0.4} \mathrm{Ce}_{0.5} \mathrm{Y}_{0.1}\right) \mathrm{O}_{2.95}$ and $\mathrm{Ba}\left(\mathrm{Zr}_{0.6} \mathrm{Ce}_{0.3} \mathrm{Y}_{0.1}\right) \mathrm{O}_{2.95}$ sintered pellets showed good chemical stability after being boiled in water or after being exposed to $\mathrm{CO}_{2}$ at $900{ }^{\circ} \mathrm{C}$ [15]. In recent stability work, the calcined $\mathrm{Ba}\left(\mathrm{Zr}_{0.8-x} \mathrm{Ce}_{x} \mathrm{Y}_{0.2}\right) \mathrm{O}_{3-\delta}$ powders synthesized by the sol-gel method exhibited a good chemical stability for $x<0.3$ after exposure to $\mathrm{CO}_{2}$ at $900{ }^{\circ} \mathrm{C}[16]$. Similarly, XRD results of $\mathrm{Ba}\left(\mathrm{Zr}_{0.8-x} \mathrm{Ce}_{x} \mathrm{Y}_{0.2}\right) \mathrm{O}_{3-\delta}$ powders prepared by the sol-gel process showed a decomposition of $\mathrm{BaCO}_{3}$ for $x \geq 0.4$ after treatment in a $\mathrm{CO}_{2}$ atmosphere at $650{ }^{\circ} \mathrm{C}$ [17].

$\mathrm{Ba}\left(\mathrm{Zr}_{0.1} \mathrm{Ce}_{0.7} \mathrm{Y}_{0.2}\right) \mathrm{O}_{3-\delta}$ (BZCY172) remained unchanged at $500{ }^{\circ} \mathrm{C}$ and exhibited sufficient stability in $2 \% \mathrm{CO}_{2}$ (with $\mathrm{H}_{2}$ ) or $\mathrm{H}_{2}$ (with $\mathrm{H}_{2} \mathrm{O}$ ) [18]. Conductivities of BZCY172 in humid $4 \% \mathrm{H}_{2} / \mathrm{Ar}$ are about $9 \times 10^{-3}$ and $2 \times 10^{-2} \mathrm{~S} / \mathrm{cm}$ at 500 and $700{ }^{\circ} \mathrm{C}$, respectively [18]. $\mathrm{Ba}_{2}$ 


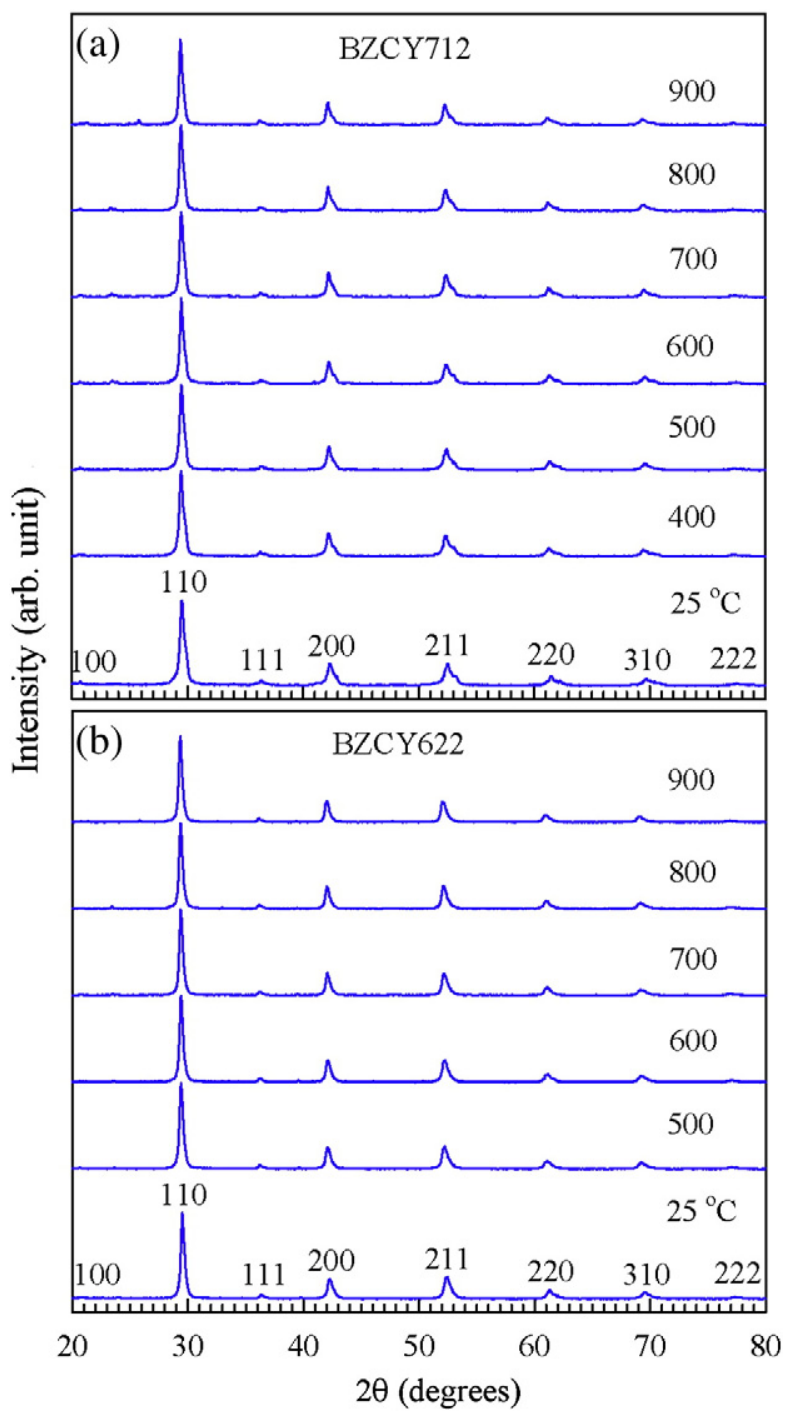

Fig. 1. XRD spectra of calcined (a) BZCY712 and (b) BZCY622 without addition of LiF in $1 \mathrm{~atm} \mathrm{CO}_{2}$ upon heating.

$\left(\mathrm{Ca}_{0.75} \mathrm{Nb}_{0.59} \mathrm{Ta}_{0.66}\right) \mathrm{O}_{6-\delta}, \mathrm{Ba}_{2}\left(\mathrm{Ca}_{0.75} \mathrm{Nb}_{0.66} \mathrm{Ta}_{0.59}\right) \mathrm{O}_{6-\delta}$, and $\mathrm{Ba}_{2}\left(\mathrm{Ca}_{0.79}\right.$ $\left.\mathrm{Nb}_{0.66} \mathrm{Ta}_{0.55}\right) \mathrm{O}_{6-\delta}$ showed long-term stability in boiling water and $\mathrm{CO}_{2}$ at $800{ }^{\circ} \mathrm{C}$ [19]. In-situ XRD and post Raman spectra of $\mathrm{Ba}$ $\left(\mathrm{Zr}_{0.6} \mathrm{Ce}_{0.2} \mathrm{Y}_{0.2}\right) \mathrm{O}_{2.9}$ (BZCY622) and $\mathrm{Ba}\left(\mathrm{Zr}_{0.8} \mathrm{Y}_{0.2}\right) \mathrm{O}_{2.9}$ (BZY82) exhibited a sufficient thermal stability in $1 \mathrm{~atm} \mathrm{CO}_{2}$ without obvious decomposition [20]. Conductivities of $\mathrm{Ba}\left(\mathrm{Zr}_{0.8-x} \mathrm{Ce}_{x} \mathrm{Y}_{0.2}\right) \mathrm{O}_{2.9}$ synthesized without LiF for $x=0.8,0.5,0.3$, and 0.0 in wet $\mathrm{H}_{2}$ at $700{ }^{\circ} \mathrm{C}$ are $1.47 \times 10^{-2}, 1.14 \times 10^{-2}, 7.10 \times 10^{-3}$, and $5.68 \times 10^{-3} \mathrm{~S} / \mathrm{cm}$, respectively [21].

Lithium fluoride ( $\mathrm{LiF}$ ) has been used as a sintering aid to reduce the sintering temperature and also to enhance density in SOFC ceramics [22]. However, there is not much knowledge on the effects of adding $\mathrm{LiF}$ on thermal stability under $\mathrm{CO}_{2}$ atmosphere. In this work, in-situ temperature-dependent XRD and micro-Raman scattering were employed to investigate the effect of $7 \mathrm{wt}$.\% LiF-addition on thermally structural stability of calcined $\mathrm{Ba}\left(\mathrm{Zr}_{0.7} \mathrm{Ce}_{0.1} \mathrm{Y}_{0.2}\right) \mathrm{O}_{2.9}$ (BZCY712) and $\mathrm{Ba}$ $\left(\mathrm{Zr}_{0.6} \mathrm{Ce}_{0.2} \mathrm{Y}_{0.2}\right) \mathrm{O}_{2.9}$ (BZCY622) powders in $1 \mathrm{~atm}$ of flowing $\mathrm{CO}_{2}$. The post micro-Raman spectra were obtained after exposure to $\mathrm{CO}_{2}$ at high temperatures.

\section{Experimental}

$\mathrm{Ba}\left(\mathrm{Zr}_{0.8-x} \mathrm{Ce}_{x} \mathrm{Y}_{0.2}\right) \mathrm{O}_{2.9}$ (BZCY: $x=0.1$ and 0.2 ) ceramic powders were synthesized by the glycine-nitrate process and then were
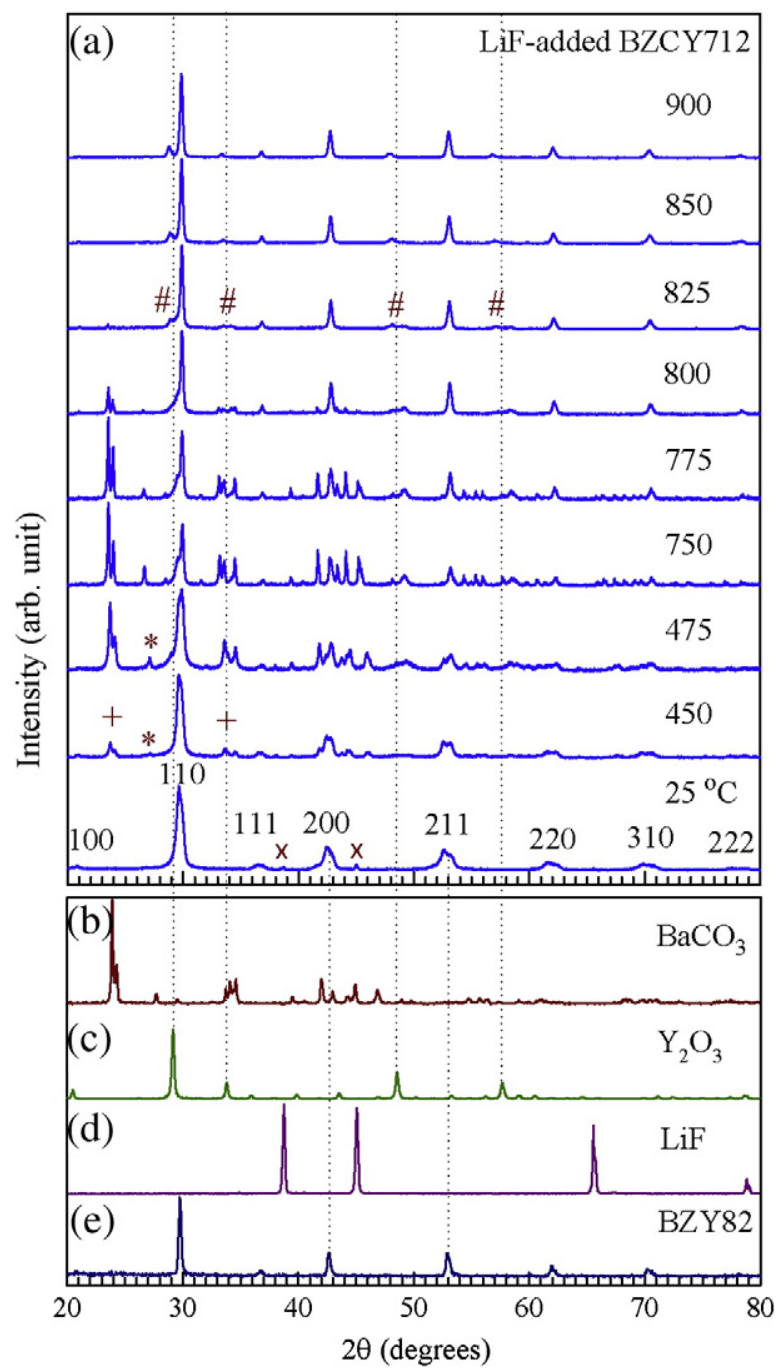

Fig. 2. (a) XRD spectra of 7 wt.\% LiF-added $B Z C Y 712$ in $1 \mathrm{~atm} \mathrm{CO}_{2}$ upon heating. The XRD spectra of (b) $\mathrm{BaCO}_{3}$, (c) $\mathrm{Y}_{2} \mathrm{O}_{3}$, (d) $\mathrm{LiF}$, and (e) calcined BZY82 powders (without $\mathrm{LiF})$. "+", “*”, "\#”, and " $\times$ " indicate $\mathrm{BaCO}_{3}$, possible $\mathrm{Ba}_{3} \mathrm{Ce}_{2}\left(\mathrm{CO}_{3}\right)_{5} \mathrm{~F}_{2}$ (or $\left.\mathrm{CeCO}_{3} \mathrm{~F}\right), \mathrm{Y}_{2} \mathrm{O}_{3}$ like compound, and LiF, respectively. The dotted lines are guides for eyes.

calcined at $1300{ }^{\circ} \mathrm{C}$ in laboratory air for $5 \mathrm{~h}$ to ensure a single perovskite phase. The $7 \mathrm{wt}$.\% LiF powder was added in calcined BZCY powders before the milling process. After the milling process, the asprepared LiF-added BZCY solution was dried into powder in an oven. For in-situ X-ray diffraction measurements, a high-temperature Rigaku Model MultiFlex X-ray diffractometer was used. In our present experimental results, separate peaks for these two wavelengths could not be resolved. As-prepared LiF-added BZCY ceramic powders were placed and smoothly pressed on the platinum sample holder. The temperature was raised in steps from room temperature in $1 \mathrm{~atm}$ of flowing $\mathrm{CO}_{2}$. Each XRD scan was taken after holding the sample at the setting temperature for about $10 \mathrm{~min}$ to ensure a complete reaction with $\mathrm{CO}_{2}$. In addition, the XRD and micro-Raman spectra were measured after subsequent exposure to $\mathrm{CO}_{2}$ at $850{ }^{\circ} \mathrm{C}$ for previously calcined (at $1200{ }^{\circ} \mathrm{C}$ in air for $5 \mathrm{~h}$ ) $7 \mathrm{wt}$.\% LiF-added BZCY powders. The post XRD and micro-Raman spectra were also obtained for $7 \mathrm{wt} . \%$ LiF-added BZCY after calcining in air at $1400{ }^{\circ} \mathrm{C}$ for $5 \mathrm{~h}$.

A double grating Jobin Yvon Model U-1000 double monochromator with 1800 grooves/mm gratings and a nitrogen-cooled CCD as a detector were employed for micro-Raman scattering. A Coherent Model Innova 90 argon laser with $\lambda=514.5 \mathrm{~nm}$ was used as an excitation source. 


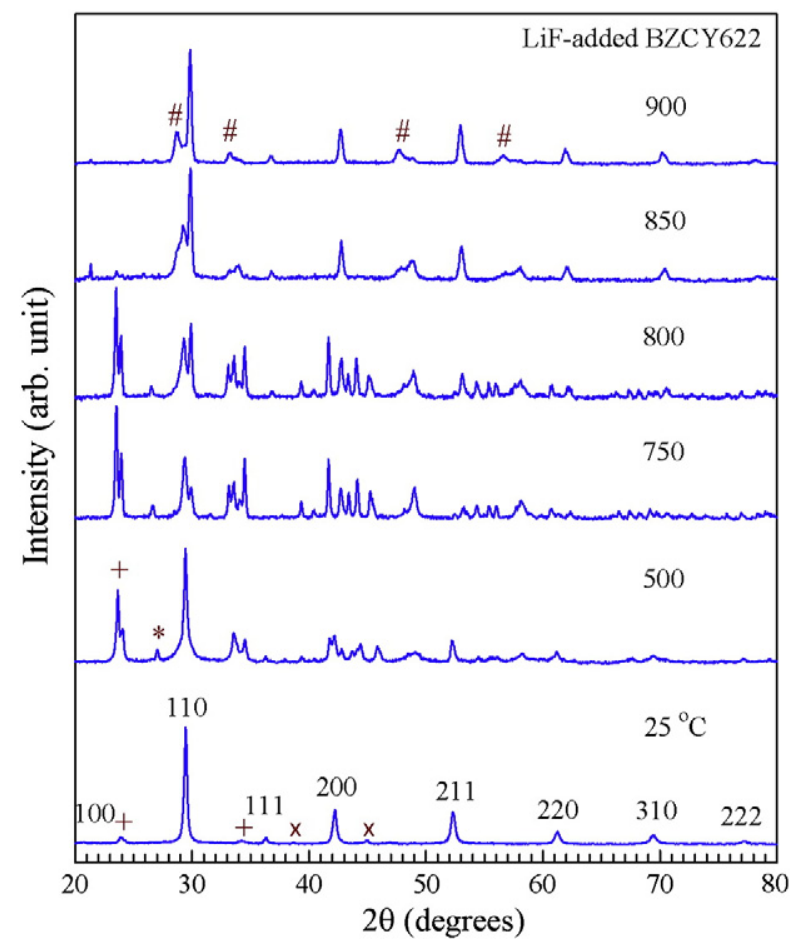

Fig. 3. XRD spectra of LiF-added BZCY622 upon heating in $1 \mathrm{~atm} \mathrm{CO}_{2}$. "+", “*”, “\#”, and " $\times$ " indicate $\mathrm{BaCO}_{3}$, possibly $\mathrm{Ba}_{3} \mathrm{Ce}_{2}\left(\mathrm{CO}_{3}\right)_{5} \mathrm{~F}_{2}$ (or $\mathrm{CeCO}_{3} \mathrm{~F}$ ), $\mathrm{Y}_{2} \mathrm{O}_{3}$-like compound, and LiF, respectively.

\section{Results and discussion}

Fig. 1 shows the temperature-dependent $X R D$ spectra of calcined $\mathrm{Ba}\left(\mathrm{Zr}_{0.7} \mathrm{Ce}_{0.1} \mathrm{Y}_{0.2}\right) \mathrm{O}_{2.9}(\mathrm{BZCY} 712)$ and $\mathrm{Ba}\left(\mathrm{Zr}_{0.6} \mathrm{Ce}_{0.2} \mathrm{Y}_{0.2}\right) \mathrm{O}_{2.9}$ (BZCY622) ceramic powders without addition of $\mathrm{LiF}$ in $1 \mathrm{~atm}$ of flowing $\mathrm{CO}_{2}$ from 25 to $900{ }^{\circ} \mathrm{C}$. The calcined BZCY712 and BZCY622 powders exhibit a good thermal stability in $\mathrm{CO}_{2}$ without apparent second phase or chemical decomposition upon heating. The main diffraction peaks of calcined BZCY712 and BZCY622 powders include (100), (110), (111), (200), (211), (220), (310), and (222), suggesting a simple-cubic perovskite structure [23].

Figs. 2(a) and 3 shows the temperature-dependent XRD spectra of as-prepared LiF-added $\mathrm{Ba}\left(\mathrm{Zr}_{0.7} \mathrm{Ce}_{0.1} \mathrm{Y}_{0.2}\right) \mathrm{O}_{2.9}$ (BZCY712) and $\mathrm{Ba}$ $\left(\mathrm{Zr}_{0.6} \mathrm{Ce}_{0.2} \mathrm{Y}_{0.2}\right) \mathrm{O}_{2.9}$ (BZCY622) powders in $1 \mathrm{~atm}$ of flowing $\mathrm{CO}_{2}$ upon heating. To identify possible chemical decomposition, the XRD spectra of $\mathrm{BaCO}_{3}, \mathrm{Y}_{2} \mathrm{O}_{3}$, and $\mathrm{LiF}$ powders were obtained at room temperature as shown in Fig. 2(b)-(d). The main diffraction peaks of as-prepared LiF-added BZCY712 and BZCY622 powders at $25^{\circ} \mathrm{C}$ include (100), (110), (111), (200), (211), (220), (310), and (222), suggesting a simple-cubic perovskite structure [23]. The cubic lattice parameters $(a)$ at $25^{\circ} \mathrm{C}$ are $4.258 \AA$ and $4.286 \AA$ respectively for LiFadded BZCY712 and BZCY622 powders estimated from the (110) peaks $\left(2 \theta=29.65^{\circ}\right.$ and $\left.29.45^{\circ}\right)$. With estimated values from (200) and (211) reflections, the standard deviation is about $0.004 \AA$ for both BZCY712 and BZCY622 powders. The lattice parameter of BZCY622 is slightly greater than that of BZCY712 because the radius of $\mathrm{Ce}^{4+}$ $\left(R^{\mathrm{VI}}=0.87 \AA\right)$ is larger than for $\mathrm{Zr}^{4+}\left(R^{\mathrm{VI}}=0.72 \AA\right)$ [24]. A minor broad shoulder seen in the high-2 $\theta$ XRD peaks of BZCY712 possibly associates with BZY82, whose XRD spectrum is given in Fig. 2(e). The dotted lines indicate the structural correlation between BZCY712 and BZY82 at room temperature.

Upon heating in $1 \mathrm{~atm}$ of flowing $\mathrm{CO}_{2}$, the XRD spectra remain almost the same below $450{ }^{\circ} \mathrm{C}$ without obvious decomposition. However, above $450^{\circ} \mathrm{C}$ several decomposition peaks appear in LiFadded BZCY712 and BZCY622 [Figs. 2(a) and 3] as denoted by "+" and “*”, indicating $\mathrm{BaCO}_{3}$ and possibly $\mathrm{Ba}_{3} \mathrm{Ce}_{2}\left(\mathrm{CO}_{3}\right)_{5} \mathrm{~F}_{2}$ (or $\mathrm{CeCO}_{3} \mathrm{~F}$ ).

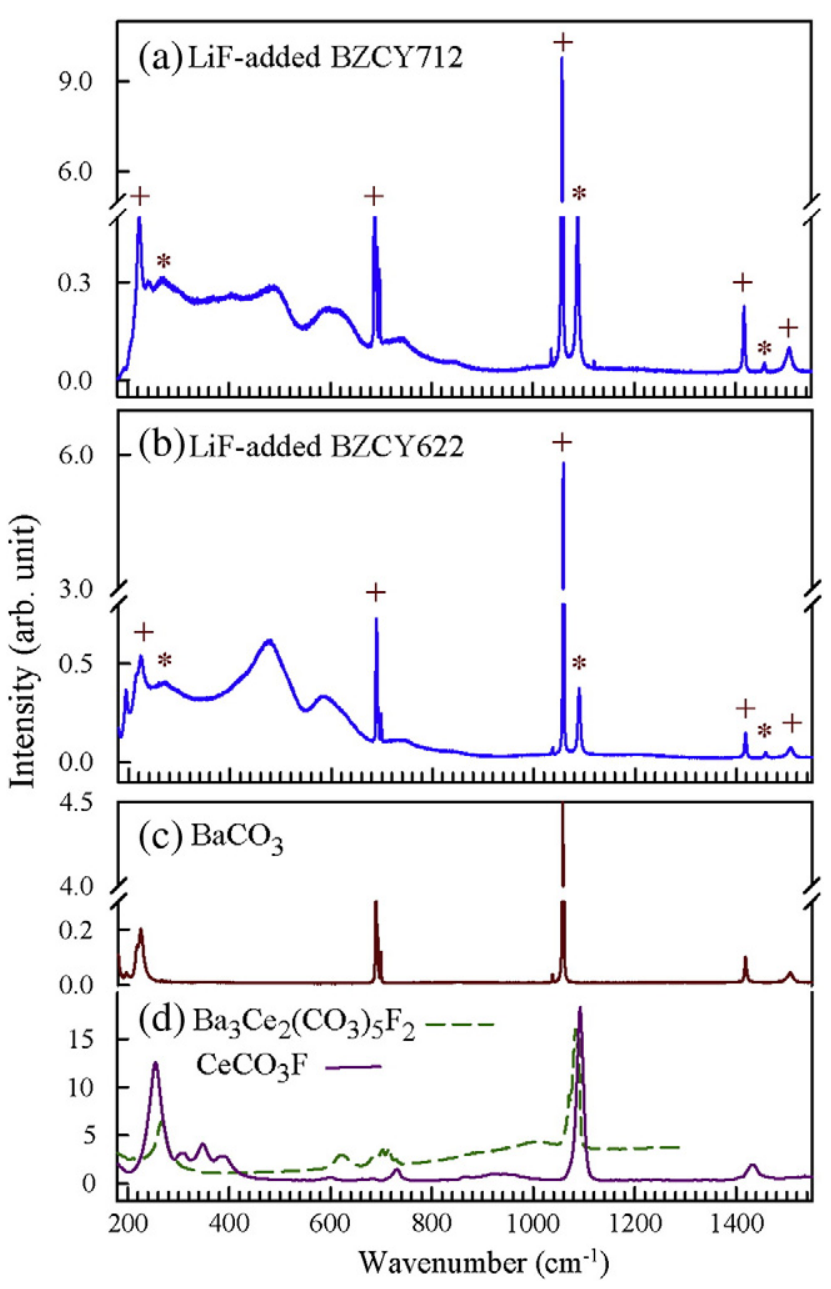

Fig. 4. Post Raman spectra of LiF-added (a) BZCY712, (b) BZCY622 after exposure to $1 \mathrm{~atm} \mathrm{CO}_{2}$ from $900{ }^{\circ} \mathrm{C}$, (c) $\mathrm{BaCO}_{3}$, and (d) $\mathrm{Ba}_{3} \mathrm{Ce}_{2}\left(\mathrm{CO}_{3}\right)_{5} \mathrm{~F}_{2}$ and $\mathrm{Ce}\left(\mathrm{CO}_{3}\right) \mathrm{F}$. "+" and "**" indicate $\mathrm{BaCO}_{3}$ and possibly $\mathrm{Ba}_{3} \mathrm{Ce}_{2}\left(\mathrm{CO}_{3}\right)_{5} \mathrm{~F}_{2}$ [or $\mathrm{Ce}\left(\mathrm{CO}_{3}\right) \mathrm{F}$ ]. [Raman spectra of $\mathrm{Ba}_{3} \mathrm{Ce}_{2}$ $\left(\mathrm{CO}_{3}\right)_{5} \mathrm{~F}_{2}$ and $\mathrm{Ce}\left(\mathrm{CO}_{3}\right) \mathrm{F}$ are cited from the database at http://rruff.info/.]

The identification of $\mathrm{Ba}_{3} \mathrm{Ce}_{2}\left(\mathrm{CO}_{3}\right)_{5} \mathrm{~F}_{2}$ (or $\mathrm{CeCO}_{3} \mathrm{~F}$ ) is mainly based on Raman spectra given in Fig. 4(d). As the temperature increases, the relative intensities of "+" and "*" peaks grow gradually up to $775^{\circ} \mathrm{C}$ and then vanish essentially above $800^{\circ} \mathrm{C}$. Several minor XRD peaks as indicated by "\#” begin to smear out near $800^{\circ} \mathrm{C}$ upon heating. Those peaks likely correspond to the $\mathrm{Y}_{2} \mathrm{O}_{3}$-like structure as compared with the XRD peaks of $\mathrm{Y}_{2} \mathrm{O}_{3}$ in Fig. 2(c).

Fig. 4(a) and (b) shows the post Raman spectra of LiF-added BZCY712 and BZCY622 powders after exposure to $1 \mathrm{~atm}$ of flowing $\mathrm{CO}_{2}$ from $900{ }^{\circ} \mathrm{C}$. To identify possible chemical decomposition, the Raman spectra of $\mathrm{BaCO}_{3}, \mathrm{Ba}_{3} \mathrm{Ce}_{2}\left(\mathrm{CO}_{3}\right)_{5} \mathrm{~F}_{2}$ and $\mathrm{CeCO}_{3} \mathrm{~F}$ are given in Fig. 4(c) and (d). The main vibrations of $\mathrm{BaCO}_{3}$ include 225, 690, 1059, and $1419 \mathrm{~cm}^{-1}$. The $\mathrm{CO}_{3}^{2-}$ ion $\left(\mathrm{D}_{3 \mathrm{~h}}\right.$ symmetry) has four normal vibration modes: $A_{1}^{\prime}(R)+A_{2}^{\prime}(I R)+E^{\prime}(R, I R)+E^{\prime \prime}(R, I R)[25]$. "R" and "IR" indicate the Raman and infrared active modes, respectively. The 690,1059 , and $1419 \mathrm{~cm}^{-1}$ vibrations respectively correspond to the doubly degenerate bending vibration $\left(E^{\prime \prime}\right)$, symmetric stretching vibration $\left(\mathrm{A}_{1}^{\prime}\right)$, and doubly degenerate asymmetric stretching vibration $\left(\mathrm{E}^{\prime}\right)$ of the $\mathrm{CO}_{3}^{2-}$ ion.

As given in Fig. $4(\mathrm{~d}), \mathrm{Ba}_{3} \mathrm{Ce}_{2}\left(\mathrm{CO}_{3}\right)_{5} \mathrm{~F}_{2}$ and $\mathrm{CeCO}_{3} \mathrm{~F}$ have two similar major Raman vibrations of 267 and 1084, and 254 and $1093 \mathrm{~cm}^{-1}$, respectively. Raman vibrations of 690,1059 , and $1419 \mathrm{~cm}^{-1}$ of $\mathrm{BaCO}_{3}$ appear in LiF-added BZCY712 and BZCY622 after exposure to $1 \mathrm{~atm} \mathrm{CO}_{2}$ from $900{ }^{\circ} \mathrm{C}$ as indicated by " +" in Fig. 4(a) and (b). In addition, 270 and $1090 \mathrm{~cm}^{-1}$ vibrations of possibly $\mathrm{Ba}_{3} \mathrm{Ce}_{2}\left(\mathrm{CO}_{3}\right)_{5} \mathrm{~F}_{2}$ (or $\mathrm{CeCO}_{3} \mathrm{~F}$ ) as indicated by "**" were also observed in LiF-added BZCY712 and BZCY622. 


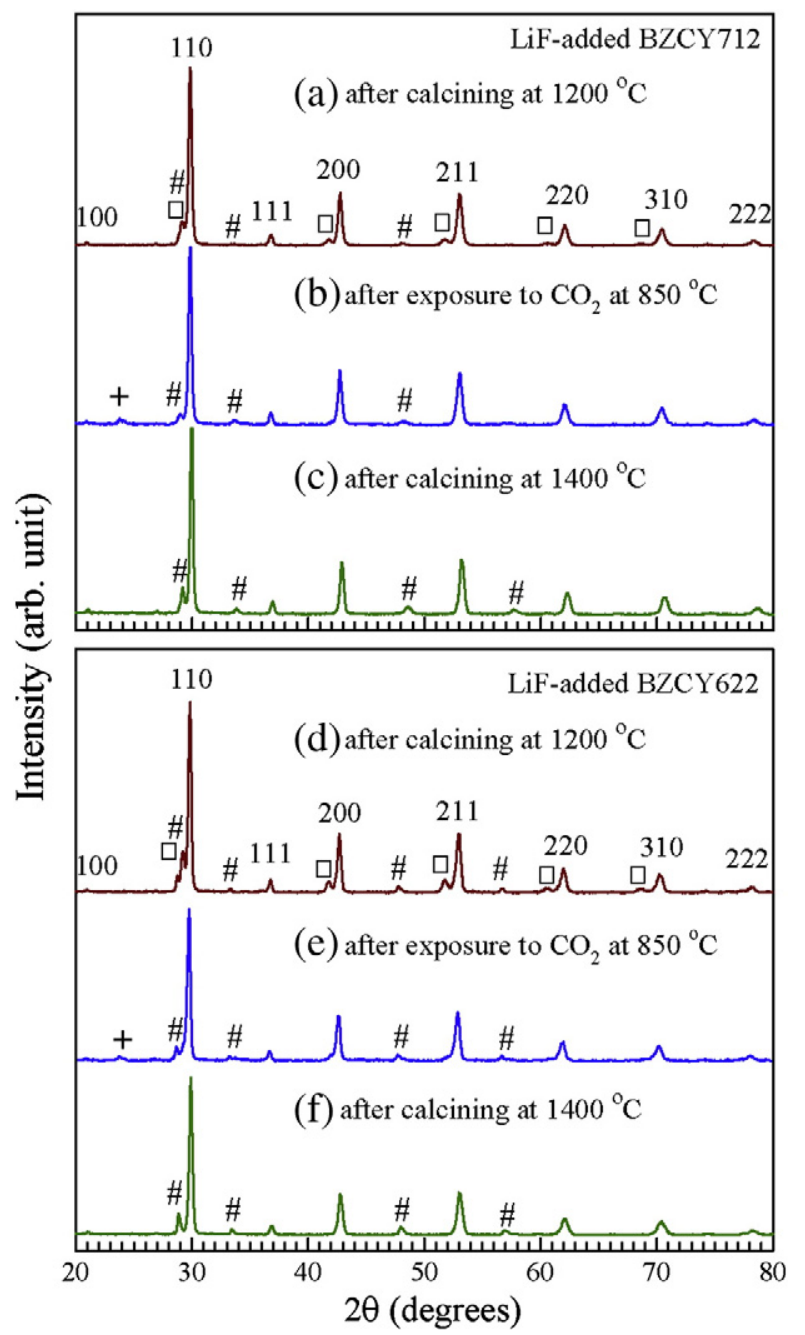

Fig. 5. Post XRD spectra of LiF-added BZCY712 and BZCY622 (a and d) after calcining at $1200{ }^{\circ} \mathrm{C}$ in air for $5 \mathrm{~h}$, (b and e) after subsequent exposure to $\mathrm{CO}_{2}$ at $850{ }^{\circ} \mathrm{C}$ for previously calcined powders at $1200{ }^{\circ} \mathrm{C}$ for $5 \mathrm{~h}$, and (c and f) after calcining at $1400{ }^{\circ} \mathrm{C}$ in air for $5 \mathrm{~h}$. "+" and "\#" indicate $\mathrm{BaCO}_{3}$ and $\mathrm{Y}_{2} \mathrm{O}_{3}$-like structure, respectively. " $\square$ " represents possibly high-cerium BZCY.

To study the effect of the calcining temperature, Fig. 5(a) and (d) show the post XRD spectra of LiF-added BZCY712 and BZCY622 powders after calcining at $1200{ }^{\circ} \mathrm{C}$ in laboratory air for $5 \mathrm{~h}$. "\#” and “ $\square$ " indicate $\mathrm{Y}_{2} \mathrm{O}_{3}$-like structure and possibly high-cerium BZCY, respectively. $\mathrm{BaCO}_{3}$ and possibly $\mathrm{Ba}_{3} \mathrm{Ce}_{2}\left(\mathrm{CO}_{3}\right)_{5} \mathrm{~F}_{2}$ (or $\mathrm{CeCO}_{3} \mathrm{~F}$ ) do not occur after calcining in air at $1200{ }^{\circ} \mathrm{C}$ and also were not observed in the post Raman spectra as shown in Fig. 6(a) and (d).

Fig. 5(b) and (e) are the post XRD spectra after subsequent exposure to $\mathrm{CO}_{2}$ at $850{ }^{\circ} \mathrm{C}$ for previously calcined (at $1200{ }^{\circ} \mathrm{C}$ for $5 \mathrm{~h}$ ) LiF-added BZCY712 and BZCY622 powders. The $\mathrm{BaCO}_{3}$ was observed in both BZCY712 and BZCY622 as indicated by "+". The Raman modes of $\mathrm{BaCO}_{3}$ were confirmed by vibrations of 690,1059 , and $1419 \mathrm{~cm}^{-1}$ as seen in Fig. 6(b) and (e). In addition, the Raman mode near $370 \mathrm{~cm}^{-1}$ which likely associates with the major vibration $375 \mathrm{~cm}^{-1}$ of $\mathrm{Y}_{2} \mathrm{O}_{3}$ [20], was observed in LiF-added BZCY712 and BZCY622 after subsequent exposure to $\mathrm{CO}_{2}$ at $850{ }^{\circ} \mathrm{C}$ as shown in Fig. 6 (b) and (e). This is consistent with the $\mathrm{Y}_{2} \mathrm{O}_{3}$-like structure as indicated by "\#" in Figs. 5 and 6.

As seen in Fig. 5(a, b, d, and e), the high-cerium XRD peaks shown by “ $\square$ " appear after calcining in air at $1200^{\circ} \mathrm{C}$, but then disappear after subsequent exposure to $1 \mathrm{~atm} \mathrm{CO}_{2}$ at $850^{\circ} \mathrm{C}$. This disappearance results from the $\mathrm{CO}_{2}$ reacting much more strongly with the highcerium material compared to the original BZCY712 or BZCY622. In (a) after calcining at $1200^{\circ} \mathrm{C} \quad \mathrm{LiF}$-added BZCY712

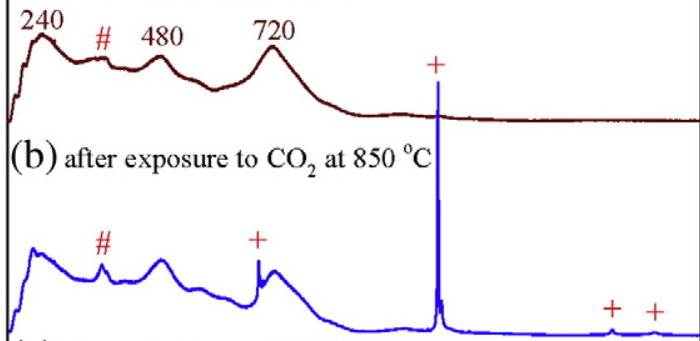

(c) after calcining at $1400{ }^{\circ} \mathrm{C}$

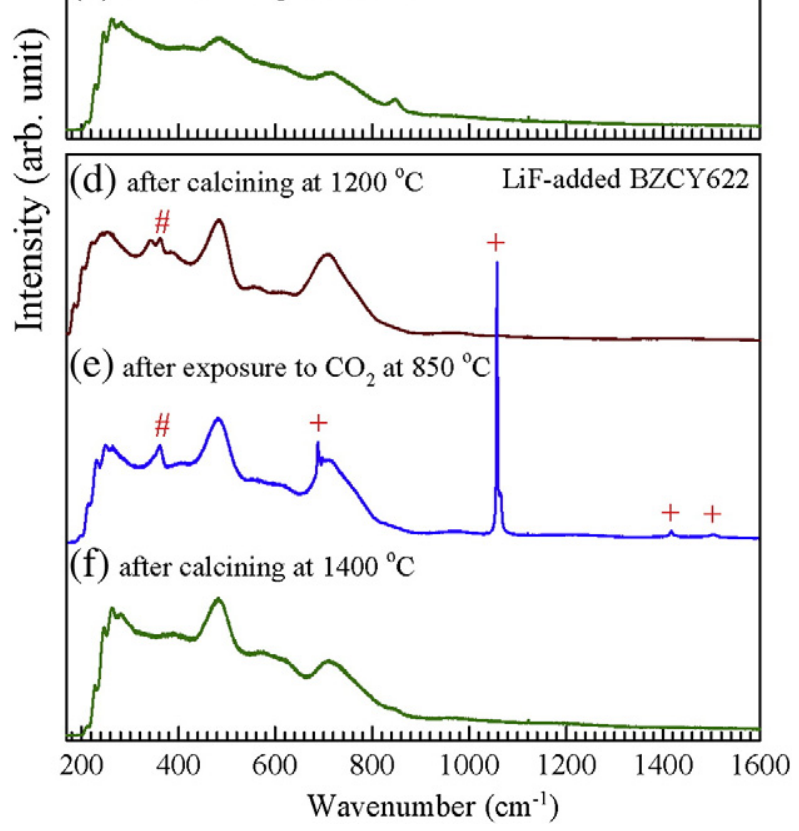

Fig. 6. Post Raman spectra of LiF-added BZCY712 and BZCY622 (a and d) after calcining at $1200{ }^{\circ} \mathrm{C}$ for $5 \mathrm{~h}$, (b and e) after subsequent exposure to $\mathrm{CO}_{2}$ at $850{ }^{\circ} \mathrm{C}$ for previously calcined powders at $1200{ }^{\circ} \mathrm{C}$ for $5 \mathrm{~h}$, and (c and f) after calcining at $1400{ }^{\circ} \mathrm{C}$ in air for $5 \mathrm{~h}$. "+ " and "\#" indicate Raman modes of $\mathrm{BaCO}_{3}$ and $\mathrm{Y}_{2} \mathrm{O}_{3}$-like structure.

addition, the $\mathrm{BaCO}_{3}$ peaks shown by "+" after the $850{ }^{\circ} \mathrm{C}$ exposure to $\mathrm{CO}_{2}$ result mostly from the loss of Ba from the high-cerium BZCY.

Fig. 5(c) and (f) show the post XRD spectra of LiF-added BZCY712 and BZCY622 powders after calcining at $1400{ }^{\circ} \mathrm{C}$ in air for $5 \mathrm{~h}$. The $\mathrm{BaCO}_{3}$ and possibly $\mathrm{Ba}_{3} \mathrm{Ce}_{2}\left(\mathrm{CO}_{3}\right)_{5} \mathrm{~F}_{2}$ (or $\mathrm{CeCO}_{3} \mathrm{~F}$ ) structures are not observed as confirmed in the Raman spectra of Fig. 6(c) and (f). The possibly high-cerium BZCY compound (as indicated by “ $\square$ ” in Fig. 5) is not observed, but the $\mathrm{Y}_{2} \mathrm{O}_{3}$-like compound still remains in the powders after calcining at $1400{ }^{\circ} \mathrm{C}$. These results suggest that LiFrelated compounds can be removed after calcining (or sintering) above $1200{ }^{\circ} \mathrm{C}$, but chemical decomposition (such as $\mathrm{Y}_{2} \mathrm{O}_{3}$-like compound) can be induced.

Comparing Fig. 6(a) and (c) for LiF-added BZCY712, and Fig. 6(d) and (f) for LiF-added BZCY622, the major Raman peaks appear near 240,480 , and $720 \mathrm{~cm}^{-1}$ in both compounds after calcining at 1200 and $1400{ }^{\circ} \mathrm{C}$. Note that the major vibrations of $\mathrm{CeO}_{2}$ and $\mathrm{ZrO}_{2}$ are 461 and $474 \mathrm{~cm}^{-1}$, respectively [26,27]. The $474 \mathrm{~cm}^{-1}$ vibration of $\mathrm{ZrO}_{2}$ corresponds to the $\mathrm{O}-\mathrm{O}$ vibration of the $\mathrm{A}_{\mathrm{g}}$ mode [26]. The $461 \mathrm{~cm}^{-1}$ of $\mathrm{CeO}_{2}$ corresponds to the $\mathrm{F}_{2 \mathrm{~g}}$ Raman-active mode of the fluorite structure [27]. Thus, the $480 \mathrm{~cm}^{-1}$ peak likely associates with the $\mathrm{O}-\mathrm{O}$ vibration in the BZCY perovskite structure.

In the recent study by Tsai et al. [22], nuclear reaction analysis (which is sensitive to elemental concentration) showed negligible residue of Li in $7 \mathrm{wt}$.\% LiF-added BZCY622 solid ceramic after sintering at $1400{ }^{\circ} \mathrm{C}$ for various dwell times [22]. The $7 \mathrm{wt}$.\% LiF-addition does not reduce conductivity, but rather slightly improves the total 
conductivity of BZCY $(x=0.0-0.4)$ ceramics measured at $700{ }^{\circ} \mathrm{C}$ in a water saturated $4 \% \mathrm{H}_{2}+96 \% \mathrm{Ar}$ atmosphere [22].

\section{Conclusions}

In-situ temperature-dependent XRD and Raman scattering spectra in $1 \mathrm{~atm}$ of flowing $\mathrm{CO}_{2}$ reveal that $7 \mathrm{wt}$.\% LiF-addition in BZCY712 and BZCY622 ceramic powders can cause chemical decomposition to $\mathrm{BaCO}_{3}$, possibly $\mathrm{Ba}_{3} \mathrm{Ce}_{2}\left(\mathrm{CO}_{3}\right)_{5} \mathrm{~F}_{2}$ (or $\mathrm{CeCO}_{3} \mathrm{~F}$ ), $\mathrm{Y}_{2} \mathrm{O}_{3}$-like compound, and high-cerium BZCY. The LiF can react with BZCY712 and BZCY622 powders above $\sim 450{ }^{\circ} \mathrm{C}$ in $\mathrm{CO}_{2}$ upon heating and then significantly causes decomposition and structural instability. After calcining at 1200 or $1400{ }^{\circ} \mathrm{C}$ for $5 \mathrm{~h}$, fluorine-related compounds, such as $\mathrm{Ba}_{3} \mathrm{Ce}_{2}$ $\left(\mathrm{CO}_{3}\right)_{5} \mathrm{~F}_{2}$ (or $\mathrm{CeCO}_{3} \mathrm{~F}$ ), do not appear after subsequent exposure to $\mathrm{CO}_{2}$ at $850{ }^{\circ} \mathrm{C}$. The post XRD and Raman spectra of LiF-added BZCY712 and BZCY622 powders after calcining at 1200 or $1400{ }^{\circ} \mathrm{C}$ for $5 \mathrm{~h}$, do not show existence of $\mathrm{Ba}_{3} \mathrm{Ce}_{2}\left(\mathrm{CO}_{3}\right)_{5} \mathrm{~F}_{2}$ (or $\mathrm{CeCO}_{3} \mathrm{~F}$ ). LiF-related compounds can be removed after calcining at high temperatures $\left(\geq 1200{ }^{\circ} \mathrm{C}\right.$ ), but a minor decomposition to the $\mathrm{Y}_{2} \mathrm{O}_{3}$-like compound could be induced. The degree of the LiF-addition effect on phase thermal stability and electrochemical properties likely depends on the working environment, especially under high-concentration $\mathrm{CO}_{2}$ atmosphere.

\section{Acknowledgements}

The authors would like to thank Dr. J. Liang for the micro-Raman scattering apparatus. This work was supported by DOE under subcontract DEAC06-76RL01830 from Battelle Memorial Institute and PNNL.

\section{References}

[1] J.P. Trembly, R.S. Gemmen, D.J. Bayless, J. Power Sources 163 (2007) 986.

[2] R.S. Gemmen, J. Trembly, J. Power Sources 161 (2006) 1084.

[3] S. Mclntosh, R.J. Gorte, Chem. Rev. 104 (2004) 4845

[4] S.M. Haile, Acta Mater. 51 (2003) 5981.

[5] C.W. Tanner, A.V. Virkar, J. Electrochem. Soc. 143 (1996) 1386.

[6] S.V. Bhide, A.V. Virkar, J. Electrochem. Soc. 146 (1999) 2038.

[7] G. Ma, T. Shimura, H. Iwahara, Solid State Ionics 110 (1998) 103.

[8] F.M.M. Snijkers, A. Buekenhoudt, J. Cooymans, J.J. Luyten, Scr. Mater. 50 (2004) 655.

[9] A. Magrez, T. Schober, Solid State Ionics 175 (2004) 585.

[10] N. Zakowsky, S. Williamson, J.T.S. Irvine, Solid State Ionics 176 (2005) 3019.

[11] B.R. Sneha, V. Thangadurai, J. Solid State Chem. 180 (2007) 2661.

[12] F. Chen, O.T. Sorensen, G. Meng, D. Peng, J. Mater. Chem. 7 (1997) 481.

[13] K.H. Ryu, S.M. Haile, Solid State Ionics 125 (1999) 355.

[14] K. Katahira, Y. Kohchi, T. Shimura, H. Iwahara, Solid State Ionics 138 (2000) 91.

[15] Z. Zhong, Solid State Ionics 178 (2007) 213.

[16] E. Fabbri, A. D'Epifanio, E.D. Bartolomeo, S. Licoccia, E. Traversa, Solid State Ionics 179 (2008) 558

[17] Y. Guo, Y. Lin, R. Ran, Z. Shao, J. Power Sources 193 (2009) 400.

[18] C. Zuo, S. Zha, M. Liu, M. Hatano, M. Uchiyama, Adv. Mater. 18 (2006) 3318.

[19] S.S. Bhella, V. Thangadurai, J. Power Sources 186 (2009) 311.

[20] C.-S. Tu, R.R. Chien, V.H. Schmidt, S.-C. Lee, C.-C. Huang, C.-L. Tsai, J. Appl. Phys. 105 (1-7) (2009) 103504.

[21] E. Fabbri, A. D'Epifanio, E.D. Bartolomeo, S. Licoccia, E. Traversa, Solid State Ionics 179 (2008) 558

[22] C.-L. Tsai, M. Kopczyk, R.J. Smith, V.H. Schmidt, Solid State Ionics 181 (2010) 1083-1090.

[23] B.D. Cullity, Elements of X-ray Diffraction, Addison-Wesley Publishing, 1978.

[24] R.D. Shannon, Acta Crystallogr. A32 (1976) 751.

[25] R.L. Frost, J.M. Bouzaid, J. Raman Spectrosc. 38 (2007) 873.

[26] B.-K. Kim, H.-O. Hamaguchi, Phys. Status Solidi B 203 (1997) 557.

[27] R.Q. Long, Y.P. Huang, H.L. Wan, J. Raman Spectrosc. 28 (1997) 29. 